\title{
LOS PERSONAJES DE CHIRBES Y LA GUERRA Y POSGUERRA ESPAÑOLAS
}

\section{CHIRBES' CHARACTERS AND THE SPANISH CIVIL WAR AND POST-WAR PERIOD}

\author{
Jacobo LLAMAS MARTÍNEZ \\ Université de Neuchâtel \\ jacobo.llamas@unine.ch
}

\begin{abstract}
A algunos criticos que me dicen que he trazado una biografia literaria de mi generación puedo asegurarles que ha sido sin premeditarlo: cada novela ha surgido como reacción ante lo que no compartía o entendía.
\end{abstract} (Chirbes, 2010: 28)

Resumen: En este trabajo se examina la recurrencia con la que los personajes de Chirbes evocan la Guerra Civil y la posguerra españolas. La vivencia de estos hechos marcó a quienes sobrevivieron al conflicto y a sus descendientes, que viven o han vivido bajo un régimen totalitario. La primacía de valores como los de sumisión, sinrazón, traición o frustración impidió la regeneración de la sociedad española durante el franquismo, la construcción de un país más ético y justo durante la Transición, y un cambio de actitud durante la democracia actual. Esta visión proyectada por los personajes coincide además con la del propio Chirbes.

Palabras clave: Rafael Chirbes. Personajes. Guerra Civil. Franquismo. Democracia.

Abstract: This work specifically explains the recurrence with which 
Chirbes's characters evoke the Spanish Civil War and post-war Spain. These circumstances marked the behavior of those who survived the conflict and their descendants, who live or have lived under a totalitarian regime. The submission, injustice, betrayal or frustration impeded the regeneration of Spanish society during Francoism, the construction of a more ethical and just country during the Transition, and a change of attitude during the current democracy. The vision projected by the characters coincides besides with the Chirbes' perspective.

Key Words: Rafael Chirbes. Characters. Spanish Civil War. Francoism. Democracy.

\section{INTRODUCCIÓN}

Las novelas de Rafael Chirbes ofrecen una gran continuidad temática, estructural y elocutiva, en especial a partir de la publicación de la La larga marcha, con la que el autor inicia una trilogía que abarca desde el final de la Guerra Civil española hasta la muerte de Franco, y en la que combina por primera vez la voz de distintos personajes mediante el uso del monólogo interior y del estilo indirecto libre ${ }^{1}$. Temáticamente destaca en ellas el contraste entre individuos opulentos y acomodados e individuos desfavorecidos y desarraigados; entre el presente y el pasado; entre la visión íntima del mundo y el comportamiento público; entre el entorno familiar y el social; entre los procesos intelectuales, que separan al hombre del animal, y los fisiológicos, que lo acercan; entre la utilidad o inutilidad del arte y el trabajo manual; entre los espacios urbanos y rurales. A estos asuntos se superponen hechos de la Guerra Civil, la posguerra, el franquismo, la Transición y los gobiernos de la democracia, que ilustran la autarquía; el hambre; la violencia; la traición; la venganza; la represión; el exilio; la apertura y el desarrollismo de los años sesenta; la lucha antifranquista; la corrupción; la codicia, la desmemoria; el auge de la construcción o la crisis económica subsiguiente ${ }^{2}$.

1. El propio Chirbes constató: “[...] en realidad he escrito una sola novela. Es decir, que todas las novelas se podrían leer como una sola" (Nichols, 2008: 224).

2. Aunque el marco histórico de las novelas de Chirbes no es objeto de examen en este trabajo, la mayor parte de los factores apuntados por el novelista durante la dictadura se sintetizan en Juliá (2003); López 
Este texto se centra en la visión desesperanzada y cruel que los personajes de Rafael Chirbes esbozan sobre la Guerra Civil y la posguerra españolas, germen de la vileza, corrupción e insolidaridad de la sociedad durante los años sesenta y setenta, y cuyas consecuencias políticas, sociales, culturales, éticas y económicas perduran en la España actual ${ }^{3}$. La lectura que efectúan estos personajes coincide además con la visión negativa que el autor tenía sobre la sociedad mundial y la española en particular, que consideraba fragmentada desde la Guerra Civil, y cuya desunión e insolidaridad continuó durante la democracia por los desmanes del liberalismo.

Para el análisis de estos aspectos se parte de los conceptos señalados por Chirbes en diferentes textos y entrevistas; de las informaciones que el narrador ofrece sobre los personajes y de las convicciones, ideas y actitudes que van mostrando los personajes de ellos mismos y de otros personajes mediante sus reflexiones, acciones y relaciones. Estos dos últimos aspectos son muy relevantes en las novelas de Chirbes, puesto que en Mimoun, La buena letra, En la lucha final, Los disparos del cazador, Los viejos amigos y Paris-Austerlitz son los personajes quienes se retratan a sí mismos y a otros personajes y los que narran la historia a través de monólogos interiores, y puesto que en La larga marcha, La caída de Madrid, Crematorio y En la orilla resulta difícil discernir en ciertos pasajes entre la voz de los personajes y la del narrador hetereodiegético, ya que el narrador adopta el tono o el punto de vista del personaje al que alude, tal y como resalta Berciano López (2015: 26-36) ${ }^{4}$.

\section{CHIRBES Y EL PERSONAJE NOVELESCO}

Los teóricos de la literatura destacan la complejidad y los abundantes problemas de categorización que plantean los personajes de ficción, los cuales admiten múltiples aproximaciones desde el punto de vista de su naturaleza (personaje y persona, individual y colectiva), desde

y Rodríguez (2010: 6) señalan algunos de los originados por la burbuja inmobiliaria de la primera década del siglo xxI, cuya génesis remontan al auge de la construcción en las playas del Mediterráneo a finales de 1950.

3. La lectura "psicocrítica" efectuada por García Pascual (2011: 109) apunta que en las novelas de Chirbes el camino de España hacia "las libertades tras la dictadura franquista fue una alternativa social, cultural y moral pactada, que trajo consigo una cadena de frustraciones en los sectores progresistas".

4. Como se puede leer más abajo, a este tipo de narrador Chirbes se refirió en algunas ocasiones como un narrador que utiliza una "tercera persona compasiva" (Armada, 2013). 
una perspectiva retórica (el decoro con el que se expresan), funcional (protagonistas, antagonistas, ayudantes, principales y secundarios), psicológica (planos y redondos, estáticos y dinámicos), histórico o social (trasuntos de una realidad histórica, de una comunidad o de un grupo social $)^{5}$.

La crítica ha estudiado parte de estos aspectos en los personajes de las novelas de Chirbes para explicar la idiosincrasia y función de los mismos, y para clarificar y describir aspectos temáticos, estructurales e ideológicos de las novelas del escritor. Ninguno de estos estudios ha planteado, sin embargo, un marco teórico para el estudio del personaje en Chirbes, deudor de los planteamientos de la novela decimonónica, que utiliza el personaje como representación de un grupo o clase social, y de la novela psicológica, que muestra las motivaciones y pasiones íntimas de los personajes para justificar por qué sus actitudes y decisiones no siempre responden a sus convicciones ni a su posición económica y social ${ }^{6}$. García de León (2006) examina cómo los temores de los personajes afectan al "sentido histórico en sus vidas", mientras que las guías de lectura sobre Los viejos amigos, La larga marcha y Crematorio de López Bernassochi y Lopez de Abiada (2011a, 2011b, 2011c) definen a los personajes a partir de sus acciones, palabras y relaciones con otros personajes, y de las apreciaciones del narrador. Echeverría (2005: 185-186), López Merino (2005) y Pozuelo Yvancos (2010: 65-66) mencionan la tipicidad y el cierto

5. Lodge (2002: 114) indica: "Los personajes son seguramente el elemento aislado más importante de la novela [...]. Sin embargo, el personaje es probablemente, de todos los aspectos del arte de la ficción, el más difícil de analizar en términos técnicos. Ello se debe en parte a la amplísima gama de tipos de personajes y de maneras de representarlos: personajes principales y secundarios, redondos y planos, personajes vistos desde dentro de su propia mente [...] y personajes vistos desde fuera por otros [...]". Kundera (1987: 12) observa: "El personaje no es un simulacro de ser viviente. Es un ser imaginario. Un ego experimental". Maestro (1994) revisa los enfoques sobre el estudio del personaje literario y aplica un análisis funcional al estudio de los personajes del cuento de Julia Ibarra la Melodramática vida de Carlota-Leopolda; para Maestro (1994: 462) "el personaje es una unidad sintáctica del relato, como las funciones, el tiempo y el espacio, también elementos estructurales [...] y se configura como unidad de función, porque puede delimitarse funcionalmente al ser sujeto de acciones propias, como unidad de sentido, ya que es objeto de la conducta de otros personajes y puede delimitarse por relación a ellos, y como unidad de referencias lingüísticas, es decir, como unidad de todas aquellas referencias lingüísticas y predicados semánticos que se dicen sobre él". Una síntesis sobre la concepción del personaje en la novela en Bobes Naves (1993: 144-165), Garrido Domínguez (1996: 103-167) o Sánchez Alonso (1998). Otras consideraciones sobre el personaje literario en Wood (2009: 79-105).

6. Benito Pérez Galdós fue uno de los principales referentes de la novela realista española para Chirbes, Faulkner lo fue en el ámbito de la novela psicológica anglosajona. No obstante, Chirbes también se fija en el decoro, Berciano López (2015: 29) destaca el habla andina del personaje de Liliana en En la orilla, y se podría resaltar igualmente la expresión clara y precisa de Rubén Bertomeu en Crematorio, que se corresponde con su elevada formación y su lucidez intelectual, o la expresión más burda e irreflexiva de Collado, acorde con sus escasos estudios y a los bajos fondos que frecuenta, pero estos aspectos exceden el objetivo de este trabajo. 
maniqueísmo de los personajes de Chirbes en La larga marcha, La caída de Madrid y Crematorio, respectivamente. Santamaría Colmenero (2013: 156), en cambio, justifica la presencia de "personajes-tipo" en La larga marcha, que "obedece a una concepción de la historia de España como lucha de clases", y en La caída de Madrid, en la que la mirada de los personajes ofrece "una multiplicidad de formas de entender y vivir las últimas horas de vida de Franco" (Santamaría Colmenero, 2013: 159)7.

Los textos de carácter ensayístico que Chirbes compuso para charlas y conferencias demuestran más interés por los valores semánticos del narrador, el punto de vista, la organización de la trama, el tiempo y el espacio o el discurso verbal que por los de los personajes, pese a que estos se convierten en narradores y actores, y en seres que habitan en un momento y un lugar determinado ${ }^{8}$. En estos escritos las referencias a ellos son pocas y bastante marginales, salvo en los textos titulados Material de derribo (Chirbes, 2002: 91-103) y Lecciones cervantinas (Chirbes, 2010: 87-111), en los que Chirbes ofreció claves para entender el uso que hizo del personaje en su propia obra al tratar de los de los personajes de Si te dicen que caí, de Juan Marsé, y de Cervantes:

Como decía Cernuda de Galdós, Marsé es tan grande que sabe colocarse a la altura de sus propios personajes, incluso de los que nos pueden parecer más abyectos, y se pone tan a ras de suelo que los tontos y los pedantes lo toman por pequeño (Chirbes, 2002: 102).

Cervantes enfrenta sus propias contradicciones a través de los personajes y las situaciones que crea; es más, los crea a unos y otras como interrogantes, y no como ilustraciones o como exposición de unas ideas sabidas de antemano: aplica esa fórmula contemporánea por la que la escritura

7. El texto de Ignacio Echeverría, que critica lo estereotipado de los personajes y el afán de ilustrar la historia colectiva "con una suerte de proselitismo pedagógico y sentimental", se publicó por primera vez en 1996 en Babelia, suplemento cultural del periódico El Pais, y suscitó el enfado de Muñoz Molina (1996), quien defendió en otro artículo la calidad literaria de La larga marcha en la que "estallan en plenitud, todos los libros anteriores, todas las historias y los personajes que uno ha ido inventando a lo largo de su vida, todas las voces que ha escuchado, dentro y fuera de sí mismo".

8. Entre estos textos sobresalen, para entender el proceder de Chirbes como novelista, los titulados $E l$ novelista perplejo, El punto de vista (Chirbes, 2002: 13-35, 69-103), Introducción: La estrategia del boomerang y De qué memoria hablamos (Chirbes, 2010: 11-37, 227-250). 
es la forma de conocimiento del novelista.

$[\ldots]$

Cervantes, que publica el grueso de su obra al filo de los sesenta, en el último tramo de su vida, se busca, melancólico, en la galería de sus personajes; ni los halaga, ni pretende ponerse por encima de ellos [...], porque acepta que el escritor no es uno u otros de los tipos que ha pintado en sus novelas, sino el interrogante que crece al moverse entre ellos; se busca a sí mismo abriéndose paso entre las razones de los otros, inquiere su forma de conducta entre las conductas ajenas, bracea en el mar de las opiniones de su época, entre las ideas en liza (Chirbes, 2010: 100, 104, 111).

El propio Chirbes expresó estas ideas en distintas entrevistas. En una de las concedidas en 2013 con motivo de la presentación de En la orilla, el escritor constató que los personajes de sus novelas tenían algo de sí mismo, de sus contradicciones, sensibilidad y demonios interiores. Entre todos, fue probablemente el personaje de Rubén Bertomeu, en Crematorio, con el que Chirbes estableció el mayor tour de force entre su persona y un personaje, al retratar a un individuo culto e inteligente, como el escritor, pero pragmático, autoritario y conspirador:

En todos los libros eres tú mismo en tus preocupaciones distribuido por una serie de personajes. Y si me preguntas quién es cada uno de los personajes que aparecen en Crematorio, diré: "Soy yo". [...] La posición del novelista es esa incertidumbre de correr de un personaje a otro. ¿Pero tú con cuál estás? Estoy en la dinámica de moverme entre unos y otros, escuchar todas las razones, y cada cual que se forme su opinión. Me decían: "Hombre, es que el protagonista de 'Crematorio' qué malísimo es, es un especulador, es horroroso, y tal”. A mí no me parece un personaje tan malo. Es un personaje, un individuo que tiene una historia, y siento hacia él una especie de piedad... En alguna novela he hablado de la tercera persona compasiva. Hay una empatía con estos personajes. [...] [En] todos los 
libros míos siempre aparezco yo por tres o cuatro lados, $y$ amigos que me conocen dice: "Joder, en esta novela todos los personajes eres tú”. Y es verdad. Juegas con eso (Armada, 2013).

En los textos anteriores Chirbes da a entender que las voces de los personajes enriquecen, con su perspectivismo, los asuntos que trata en las novelas, y que matizaron o completaron sus convicciones como persona. Chirbes se presenta así como uno de esos escritores que, según Wood (2009: 95), están "menos interesados, o quizás menos naturalmente dotados" para crear personajes variados que no se parecen nada a ellos, "pero que, sin embargo, tienen muchísimo interés en el yo"; y se aproxima una vez más a los postulados de Bajtin para quien el personaje posee, al decir de Bobes Naves (1993: 54), "un discurso propio constante, que se contrasta de inmediato con la voz del narrador, pero también con la de los otros personajes", de manera que "a través de toda la estructura de la novela, el autor no habla del personaje, sino con el personaje"".

Al caracterizar a los individuos, Chirbes diseminó sus odios y afectos, sus reflexiones e inquietudes, sus vacilaciones y dudas, incluso sus propias circunstancias vitales, de forma que se intuyen trasuntos del autor en varios de ellos: el protagonista de Mimoun es profesor de español y novelista en Marruecos, como lo fue el propio Chirbes en la Universidad de Fez durante dos cursos. En La larga marcha, José Luis del Moral y Raúl Vidal comparten circunstancias con el escritor, quien cursó, como estos personajes, parte de los estudios en un internado de León y se trasladó después a Madrid para los estudios preuniversitarios e iniciar posteriormente una carrera universitaria. Carlos, escritor homosexual en Los viejos amigos, parece otro trasunto del propio Chirbes. Incluso personajes menos afines a la personalidad del autor muestran similitudes biográficas: Ana dirige en La buena letra una carta a su hijo, que pertenece a la misma generación que el escritor, y Francisco, personaje de En la orilla, trabajó, al igual que Chirbes, como crítico gastronómico (una

9. Chirbes manifestó su acuerdo con las ideas polifónicas y el dialogismo de Bajtin en distintos lugares; por ejemplo, Chirbes (2010: 27) reconoció que su empeño como novelista se ajustaba a lo que el autor ruso afirmó "en su ensayo Sobre el discurso novelesco: 'El prosista [...] intenta decir en el lenguaje de otro lo que le concierne personalmente [...] mide su propio mundo a partir de la escala lingüística de los otros'. Bajtin ve la novela como un ejercicio de indagación, de búsqueda de uno mismo entre las historias y razones de otros; es una idea que comparto". 
biografía de Chirbes en Val, 2015) ${ }^{10}$.

Desde una perspectiva creativa, este hecho puede lastrar la opinión sobre los personajes de Chirbes, porque en bastantes casos estos no son fruto de un ejercicio de imaginación y abstracción desbordante, sino una recreación de las vivencias del autor y son susceptibles, pues, de ser una simple extensión de la personalidad del escritor. De hecho, las pocas veces que Chirbes reproduce las palabras de los personajes en diálogos directos las voces se asemejan bastante al estilo del narrador y del escritor ${ }^{11}$. El otro problema que manifiestan los personajes de Chirbes es el de su psicología y conducta, que están más determinadas por sus orígenes, clase social e intereses que por las experiencias en el relato, y por ello se juzgan en ocasiones como poco convincentes.

No obstante, estos posibles sesgos no afectan al propósito que Chirbes reservó a sus personajes: el de que fueran representativos de la sociedad española del siglo xx y comienzo del XxI, el que no resultasen unívocos ni sentimentaloides y, sobre todo, el de que sus pensamientos y razones desarrollasen, conectasen y agrupasen, con la complejidad debida, los motivos que abordó en sus textos. De este modo, por las novelas de Chirbes se suceden, con mayor o menor tipicidad, republicanos y franquistas, privilegiados y desfavorecidos, clases altas, medias y bajas, empresarios y trabajadores, personajes masculinos y femeninos, ancianos, adultos y jóvenes... Cada uno de ellos posee su propia biografía e impregnación ética y moral que, desarrolladas más prolijamente o menos, condicionan su carácter, acciones y "destinos individuales” (Jacobs 1999: 176). Así, la unión de las maneras de pensar, emociones y actitudes de los personajes recreados por Chirbes transmite una perspectiva panorámica y coral - 0 dialógica, según la proverbial categorización de Bajtin (1986: 13-71)— sobre la política, la sociedad, la economía y la cultura española desde el final de la Segunda República hasta el principio del siglo xxI. La lectura que se extrae de esta visión es negativa y abiertamente pesimista (Calvo Carilla, 2013), y tiene su origen, tal y como apreció Santamaría Colmenero

10. Chirbes (2002: 9) explicó que en sus novelas abordaba cuestiones íntimas "a través de personajes que no eran yo, o que sólo de refilón eran yo, o que eran tan yo que parecían otros".

11. Dos de los rasgos estilísticos definitorios del estilo de Chirbes y de sus narradores son las figuras de repetición y la anteposición al verbo de miembros e incisos (Llamas Martínez, 2017), y estos se repiten, por ejemplo, en los monólogos interiores de los personajes o en los diálogos en estilo directo de La caída de Madrid: “-Le doy de comer a un hijo, o, para ser más exacto, les doy de comer a los dos hijos que tengo, o ¿quieres que te dé de comer más a ti?"' (Chirbes, 2000b: 167). 
(2013: 152) en La larga marcha, en la Guerra Civil: “[para los personajes de La larga marcha], el recuerdo de lo vivido en la guerra está tan presente que les impide proyectarse en un futuro distinto, mientras que sus hijos se verán inmersos en una lucha por desprenderse del pasado y proyectarse hacia un futuro que, sin embargo, se trasluce ya como fracaso".

\section{PERSONAJES DESOLADOS}

Los individuos de las novelas de Chirbes que asistieron a la Guerra Civil se muestran como seres emocionalmente devastados por la guerra. Dos de los personajes que mejor ejemplifican este hecho son Vicente Tabarca, médico republicano de La larga marcha que tuvo que renunciar a una prometedora carrera científica y a sus convicciones al no poder huir al exilio, y el padre de Esteban en En la orilla, que luchó por la República durante la Guerra Civil y que se entregó después del conflicto para no perjudicar a su familia. Chirbes ni siquiera da nombre al padre de Esteban y subraya así la condición de ser ignorado y marginado; en el presente, el personaje, anciano y enfermo, es cuidado por el hijo, que no compartió sus ideales republicanos y que ha llevado la carpintería familiar a la ruina ${ }^{12}$ :

De joven [explica Esteban sobre su padre] ${ }^{13}$ quiso ser escultor, como quiso que lo fuera yo, pero el tumulto de la guerra frustró sus aspiraciones [...]

Se le quedaron congeladas en su año y pico de guerra y en los tres de cárcel y en la marginación que le acosó desde entonces $[\ldots]$

"En la Escuela de Artes y Oficios [...] copiábamos la plaza San Ignacio de Roma, la cúpula del Panteón, los frisos de los frontones griegos, el alzado de los templos de Paestum, los relieves del Ara Pacis de Augusto. Todo eso lo dibujé y

12. Del resto de personajes de En la orilla se conoce el nombre, pero no el apellido; López Merino (2005: 304-307) demuestra el simbolismo que el escritor concede a la onomástica en La caída de Madrid. Durante la convalecencia, el padre de Esteban no vuelve a dirigir la palabra a su hijo, sin que se aclare si no puede hacerlo, ya que su enfermedad ha obligado a extirparle la garganta, o no quiere, como parece insinuar Chirbes (más detalles en Berciano López, 2015: 42; García Larisch, 2015: 16). La figura de Vicente Tabarca se parece a la de Pedro en Tiempo de silencio, de Luis Martín Santos, otro médico e investigador al que las limitaciones económicas de la posguerra le impiden continuar con sus estudios contra el cáncer.

13. Entre corchetes se identifica al personaje al que corresponde o se refiere la reflexión del fragmento citado y a aquellos otros personajes a los que se remite. 
no lo he visto nunca... el deseo y la posibilidad de verlo los enterré el mismo día en que me subieron a una camioneta y me enviaron, con diecisiete años, al frente de Teruel, la quinta del biberón" "14 (Chirbes, 2013: 33, 53, 354).

Él [Vicente Tabarca] quería haber sido un investigador, un cientifico. Había empezado a serlo. Sus trabajos se publicaban en revistas especializadas del extranjero [...] Todo eso se ha esfumado. Y ahora sueña con microscopios y probetas, con virus y bacterias [...] y a esa añoranza se superpone como su peor y más recurrente pesadilla el recuerdo de aquel día en que el barco que esperaban no llegó al puerto de Gandia (Chirbes, 1996: 93).

Los supervivientes de la Guerra Civil se presentan, por tanto, como seres frustrados e infelices. Esto ocurre con independencia de que hayan luchado en el bando nacional o republicano, tal y como se deduce de las reflexiones de Ana, narradora protagonista de La buena letra, cuyo padre luchó en las tropas republicanas, y de las de Pedro del Moral, limpiabotas viudo de la La larga marcha que combatió del lado franquista y aspiraba a ser reconocido con un puesto en la administración ${ }^{15}$. Chirbes alude en este segundo caso a la estafa que supuso la Guerra para aquellos seres más humildes, a quienes se habían prometido recompensas y una mejora de su posición social a cambio de arriesgar la vida en el frente por Franco; sin embargo, una vez acabada la contienda compartieron la misma pobreza e impotencia de aquellos a los que habían derrotado ${ }^{16}$ :

14. Las comillas indican que el pasaje ya figura en cursiva en la novela de Chirbes por tratarse de un texto escrito por el padre de Esteban y que este último descubre tras las hojas de un calendario de los años sesenta y transcribe.

15. Amar Sánchez (2010) estudia un amplio corpus de novelas motivadas por la Guerra Civil española y por las dictaduras española y sudamericanas a partir de la dicotomía ganadores y perdedores; Coen (2012) aplica este planteamiento a los personajes de Crematorio.

16. Para los personajes de Crematorio, La larga marcha y Los viejos amigos véanse las guías de lectura elaboradas por López Bernasocchi y López de Abiada (2011a, 2011b, 2011 c). Chirbes reconoció, con respecto a La buena letra y Los disparos del cazador, que uno de los objetivos de estas novelas era recordar el dolor de quienes sufrieron la guerra: “[ ...] busqué condensar las heridas que dejó [...] las traiciones, los cambios de bando, la ilegitimidad de la riqueza acumulada durante todos aquellos años, pero también el sufrimiento, la lucha por la dignidad de los vencidos. La ilegalidad" (Chirbes, 2015: 59). Los críticos literarios alemanes que concedieron a Chirbes el premio SWR-Bestenliste por La buena letra y La larga marcha resaltaron la forma en que el novelista evocó "las humillaciones, el dolor, el vacío y los daños ocultos que llegan hasta la vida diaria" (Aniorte, 2011: 152). 
[Ana] No había nada que salvar. El tiempo lo deshacía todo, lo convertía en polvo, y luego soplaba el viento y se llevaba ese polvo.

$[\ldots]$

Nos ahogábamos en una miseria peor que la que trajo la guerra

$[\ldots]$

La necesidad no deja ningún resquicio a los sentimientos (Chirbes, 2000a: 104, 107, 129).

[Pedro del Moral] deseaba que aquel tren que se había llevado sus piernas lo llevara a Mequinenza de nuevo, a las noches crueles, pero inocentes, de la guerra, llena de estrellas que temblaban con un resplandor rojizo cada vez que estallaba un obús a lo lejos; a aquel lugar de Santander, con el río en el que se bañaban desnudos los soldados, la ropa esparcida bajo los castaños, y las mujeres que lloraron en silencio mientras él les pasaba por la cabeza la maquinilla de rapar. Sobre el suelo empedrado de la plaza cayeron mechones negros que el viento de la tarde esparció. Quería que la locomotora lo llevara hacia atrás, hacia su vieja casa de Fuentes de San Esteban, hacia las tardes de domingo de entonces, cuando Asunción lo veía llegar desde detrás de los visillos de la ventana (Chirbes, 1996: 144-145).

La desazón y la degradación moral que supone la Guerra y la posguerra consume a los personajes de las novelas de Chirbes y repercute en su entorno ${ }^{17}$. El más inmediato es el de la familia, que aglutina la

17. Las actitudes emponzoñadas de los personajes también afectan a los espacios naturales que los rodean. En En la orilla, el pantano sirvió para arrojar a los fusilados durante la guerra y el franquismo; en época democrática se ha convertido en un vertedero incontrolado que oculta la podredumbre de la nueva sociedad, cínica y corrupta. En Crematorio (2007: 10), la vorágine constructora de Rubén Bertomeu, protagonista principal de la novela, ha destruido la belleza natural de la costa valenciana: "Las ruedas del coche hacen crujir la capa de arena que cubre el asfalto en este tramo de la calle cercano a la playa... Las bolsas de basura... cuelgan de los apartamentos, se amontonan junto a los contenedores... Impregnan con sus pesadas emanaciones el mustio aire yodado que exhala el mar". García Larisch (2015) analiza la importancia del olfato en En la orilla. 
desesperanza y el desamparo de cada uno de sus miembros. Las relaciones entre ellos son hostiles: esposos y hermanos se traicionan por cobardía o por intentar sobrevivir y medrar, e ilustran cómo el hogar, en lugar de servir de apoyo y consuelo, se vuelve un ente opresivo y amargo. La caracterización de la familia se aleja así de la imagen religiosa y bien avenida que el franquismo predicaba de ella:

[Ana] Cada noche me preguntaba si es que los demás [de la familia] no se daban cuenta de que la miseria no nos dejaba querernos. Era como vivir entre ciegos (Chirbes, 2000a, 49).

[Esteban] Fue al volver de la guerra cuando mi padre pensó quedarse en el pantano hasta que pasaran los malos tiempos, pero mi madre lo convenció para que se presentara en el ayuntamiento y se entregara.

Desde los días en que mi madre le pedía que se entregara y la abuela le exigía que se marchara, que se escondiese donde nadie pudiera encontrarlo $[\ldots]$

"Labré unas figuritas que le envié a mi mujer por medio de un vecino - a mi padre le hice un llavero precioso, con la hoz y el martillos metidos en una estrella de cinco puntas-, las tiraron, las enterraron, las quemaron antes de que los nacionales entraran en Olba" (Chirbes, 2013: 95, 348).

Con la misma dedicación con que había defendido las propiedades de los Amado, con la misma minuciosidad contable [...] Eloísa [Amado] exigió su parte de las ventas de los animales $y[\ldots]$ por las tierras que quedarían anegadas cuando concluyera la construcción del pantano [...] Desde el mismo día que anunció su próxima boda con Martín Pulido, guardia civil destinado en Fiz, y nacido en Montalto, provincia de Badajoz, Eloísa había decidido que su familia era ahora otra, la de su futuro marido, y que era por ella por la que tenía que pelear con el mismo vigor con el que había peleado por la de sus padres y hermanos 
(Chirbes, 1996: 168-169).

[José Luis del Moral] Su hermano [Ángel del Moral, de Tejares como púgil $]^{18}$ nunca le respondió y fue su padre [Pedro del Moral] quien acabó enviándole la foto dedicada del boxeador que él había solicitado

[...]

Además, que a su hermano le daba todo igual. Ganaba dinero y lo gastaba sin acordarse para nada de ellos. José Luis pensó que le hubiera gustado encontrarse con su hermano en la casa de Tejares, como en los viejos tiempos, o que lo hubiera invitado a visitar el piso en el que vivía cerca de la Alamedilla, pero no fue así (Chirbes, 1996: 184, 265).

El resentimiento y el desarraigo familiar afectan a su vez a las dinámicas sociales, y facilitan la represión del régimen franquista, que aprovecha la condición viciada de los individuos y la sordidez y anomia que los cerca para potenciar la autoridad. En ese ambiente abundan además los advenedizos y colaboracionistas, que intentan granjearse el favor de los dirigentes fascistas para salir de la miseria a costa de sus iguales. Se establece de este modo una lucha despiadada por la supervivencia ${ }^{19}$ :

\section{[Vicente Tabarca] Triunfaban las nulidades, a falta de competencia. Lo bueno había sido expulsado, o permanecía}

18. Chirbes (2007: 52) alude a él como un "ex boxeador sonado". El autor reconoció que le gustaba recuperar el nombre de los personajes de distintas novelas como divertimento o guiño con el lector (en Armada, 2013); en La buena letra ya se leen apellidos como el de Císcar (Tomás) o Mullor (Raimundo), que se repiten en Los disparos del cazador, cuyo protagonista es Carlos Císcar, o en Crematorio, donde Juan Mullor es un catedrático de literatura y marido de Silvia Bertomeu. Estos apellidos — Císcar, Mullor, o el de Ricart en $L a$ caída de Madrid - pertenecen a linajes ilustres de la costa mediterránea española desde época medieval o pueden relacionarse, como el de Bertomeu, con grupos empresariales o inmobiliarios, como sucede con Ruben Bertomeu en Crematorio.

19. López Merino (2005: 295-296) estudia esta lucha por la vida en La Caida de Madrid, donde considera que Chirbes describe la sociedad "como ecosistema en proceso de cambio en el que los individuos de las distintas especies (clases) se encuentran en un proceso dinámico de acciones y reacciones, de ajuste y regulación, con el fin de mantener la pirámide ecológica (es decir, social) [...] la novela de Chirbes defiende que en la lucha social medran aquellos cuyos cambios son ventajosos, y se originan así, en casos extremos, nuevas clases o cambios de clase". Téngase en cuenta además que parte de los personajes de las novelas de Chirbes adeptos al régimen de Franco disfrutan, al igual que el dictador, con la caza: son depredadores que defienden su territorio (España), su poder (el de las armas) y su especie (su condición de privilegiados). A este respecto resulta muy ilustrativo el título Los disparos del cazador, cuarta de las novelas publicadas por Chirbes. 
maniatado, y, en el país de los ciegos, se peleaban entre sí las legiones de tuertos en busca del éxito: enchufados, usurpadores, estraperlistas, gente sin escrúpulos [...] Todo estaba corrompido y, para sobrevivir, no quedaba más remedio que mancharse en tareas indignas (Chirbes, 1996: $51)$.

Desde que acabó la guerra, [Raúl Vidal] había tenido que conformarse con continuar como un peón de Vías y Obras, viendo cómo ascendian rápidamente los que llegaban de fuera avalados por recomendaciones que siempre destacaban su conducta patriótica en el bando nacional, o los que, habiendo trabajado con él antes de la guerra, habian actuado en el ferrocarril como colaboracionistas (Chirbes, 1996: 27).

[Esteban aludiendo a los recuerdos de su padre] Habias visto a tus vecinos envueltos en la bandera tricolor durante los años de la República y los primeros días después de la rebelión militar, cuando estaban convencidos de que iban a ganar la guerra, y los viste a la vuelta, cuando todo había concluido: hacian cola ante el ayuntamiento para denunciar, se apresuraban a darles pistas a los matones susurrándoles en qué escondite, en qué casa de campo, en qué desván [...] Todo valía para salvarse (Chirbes, 2013: 156-157).

\section{SOCIEDAD INSOLIDARIA}

Siguiendo con los planteamientos biológicos de López Merino (2005), el "ecosistema" social de las novelas de Chirbes, derivado de la Guerra Civil y las duras condiciones de vida de la posguerra, impide la regeneración de la familia y de la sociedad durante las décadas siguientes. En la familia, porque los lazos afectivos no se han recuperado y porque aquellos que no vivieron la guerra y las represalias posteriores no alcanzan a comprender la magnitud del conflicto ni de la dictadura, y cuestionan la 
ira o la pasividad de quienes sí las padecieron ${ }^{20}$; y en la sociedad, porque el ambiente inficionado condiciona la manera en la que los personajes perciben, actúan y reaccionan ante los procesos sociales en los que están implicados: ya sea la defensa del régimen o la lucha antifranquista. Los primeros intentan mantener la posición de privilegio, mientras que los segundos tratan de revertir una situación que les perjudica social o económicamente, más que de establecer una sociedad libre, solidaria y justa. Los personajes de Chirbes proyectan así una visión nihilista y naturalista del hombre, por la cual el individuo y el ambiente que los circunda son inseparables ${ }^{21}$ :

[Apuntes del padre de Esteban] La guerra lo fastidió todo. He necesitado decírselo a mi hijo Germán [hermano de Esteban] antes de que se fuera al servicio militar, seguramente para mostrarle que yo había peleado en una gran batalla, pero que él tenía que luchar en la suya, no es batalla pequeña mantener la dignidad entre todas las bestias fascistas con que va a encontrarse en el cuartel, $y$ más siendo hijo de quien es (Chirbes, 2013: 348).

[Rita] El antifranquismo era una patente de corso para casi todo [...] Fuimos así, porque los tiempos eran así, del mismo modo que los niños de hoy son clientes naturales de El Corte Inglés desde el día en que nacen, nosotros, con el franquismo de por medio, fuimos clientes naturales de la revolución (Chirbes, 2003: 58-59).

20. García de León (2006) estudia el "miedo a la muerte" como otro de los factores que determina las relaciones entre padres (la generación de la Guerra Civil) e hijos (la de la posguerra española) en las novelas de Chirbes. De hecho, La larga marcha tuvo como título provisional el de Padres e hijos.

21. Chirbes (2010: 199) comparte estos presupuestos expresados por Balzac y Zola: "La novela forma parte de los materiales con los que se construye eso que se llama el espíritu del tiempo ('il y a une atmosphère des idèes' decía Balzac), que se refleja en los temas que trata tanto como en la organización del texto". Zola (2002: 67) explica: "[...] el circulus social es idéntico al circulus vital tanto en la sociedad como en el cuerpo humano, existe una solidaridad que une [...] a los diferentes órganos entre sí, de manera que, si un órgano se pudre, muchos otros son alcanzados y se declara una enfermedad muy compleja". Morales Olivas (2006: 165, 171) subraya la relación o el contraste entre el ambiente, los sucesos y los personajes en La buena letra y Los viejos amigos. Roberto Ángel (2007) conecta el medio en el que viven los personajes de Mimoun con sus actitudes y comportamientos. Higuero (2003-2004: 137) examina la negación de ideales y valores en Los viejos amigos, donde "la creencia en la revolución [de los personajes] [...] integrantes de una célula antifranquista ha quedado simplemente reducida a motivo de charla intrascendente". 
[Rubén Bertomeu] Es que no sé cuál es tu malestar, Silvia [hija de Bertomeu], tienes veinte años. No sé exactamente qué es lo que me echas en cara. Nosotros, tu tio, Brouard, yo, tanta gente, lo que quisimos fue luchar, cada uno a nuestra manera, contra la dictadura, no tanto contra un sistema político; yo diría que la lucha fue, sobre todo, contra una sociedad cerrada, pacata, que te asfixiaba, te impedia respirar (Chirbes, Crematorio, 2007: 192).

Los personajes de La caída de Madrid manifiestan la erosión extrema a la que llegó la sociedad española después de casi cuarenta años de dictadura. La familia de José Ricart, cuya empresa prosperó gracias a su militancia franquista, se divide entre el temor de su hijo Emilio ante la posibilidad de perder su ventajosa situación con el fallecimiento de Franco; la desmemoria de su esposa Amelia Ricart; la ineptitud de uno de sus nietos afín al régimen, José Mari (nombre del antiguo presidente español José María Aznar); y la confusión del otro, Quini, universitario que abraza ideales marxistas sin una determinación clara. A este mismo clima de degeneración ideológico y moral responden el oportunista Jesús Taboada, que primero aboga por el derrocamiento del fascismo y después reniega de él para ejercer de abogado pocos meses antes de la muerte de Franco, y el obrero Lucio, sin capacidad para tomar las armas e iniciar una revolución. Por su parte, el profesor Chacón, exiliado retornado gracias a la apertura del régimen franquista en los sesenta y posible trasunto de Max Aub, actúa como contrapunto de estos y otros personajes de La caída de Madrid para sentenciar que la defunción del dictador no va a suponer grandes transformaciones, puesto que lo que vaya a suceder una vez muerto Franco habrá sido orquestado desde dentro del país por las mismas élites que apoyaron al dictador y su único objetivo es conservar la hegemonía ${ }^{22}$ :

22. Esta continuidad viene expresada en La caída de Madrid por una "pitillera [...] que perteneció a un oficial vencido y muerto en el final de la Guerra Civil [...] que llega a las manos de los combatientes nacionalistas, y que después de la guerra significará los favores que se han ido haciendo: primero el estraperlo [...] después el acomodo al final de la dictadura" (Luengo, 2004: 227), y por el personaje del profesor universitario Juan Bartos, que ya aparecía como docente en La larga marcha. Una caracterización más detallada de los personajes de La caída de Madrid se puede ver en López Merino (2005: 304-307). Otros datos en Schmitz (2006) y Orsini-Saillet (2010). Sobre la figura de Max Aub, Chirbes (2002: 118-119) escribió: "País y exilio iniciaban el mismo día de la derrota [en la Guerra Civil] caminos divergentes [...] El propio Aub tendría ocasión de comprobarlo dolorosamente cuando, en 1969, se decidió a volver en un breve viaje y descubrió que España no había sido secuestrada ni esperaba ansiosa su liberación". 
[José Mari] - Y entre la familia y la Patria tengo que elegir por fuerza la Patria, que es la que da sentido a la familia, porque tú me estás hablando de una familia en la que el padre no sé si es débil o cobarde, y el hermano es traidor, cómplice de los asesinos. Me toca elegir la Patria frente a la familia (Chirbes, 2000b: 168-169).

[Taboada dirigiéndose a Lucio] Te subes a un bidón en el metro, y dices: "Compañeros, no nos dejan hablar, esto es injusto”; pero imagínate que te dejaran hablar, ¿qué dirías? Nada. Ese día, si es que llega alguna vez [...] hablarán los especialistas [...] y ya no será Franco el que te callará (Chirbes, 2000b, 153).

[Chacón imprecando a Juan Bartos, profesor de Quini Ricart] -Los antifranquistas de los que me hablas son herederos de Franco. Lo odian como se odia al padre. No es mi caso, yo no tengo nada que ver con ellos [...] Que no me interesáis nada ni España ni los españoles, coño. Déjame en paz (Chirbes, 2000b: 187-188).

Poco antes, las palabras de Chacón a Juan Bartos predicen el acuerdo que tendrá lugar entre las élites políticas para reconvertir el régimen franquista en una democracia sin purgar los atropellos de la Guerra Civil y el franquismo (el llamado "pacto de silencio" o "cambio sin ruptura" de la Transición): la juventud formada por el régimen franquista, se le oponga o no, "son los anticuerpos que ellos mismos han creado para salvarse cuando enfermen de verdad, la vacuna para que el país siga siendo suyo" (Chirbes, 2000b: 186).

Por consiguiente, para los personajes de Chirbes la Guerra Civil es el origen de la vileza y de la falta de valores de la sociedad española posterior, cuyas consecuencias se transmiten de generación en generación y llegan hasta el presente, que perpetúa los desequilibrios sociales y la falta de fraternidad. Así lo expresan en Crematorio las figuras de Ramón Collado, melancólico y vicioso, que ayudó a medrar al constructor Rubén Bertomeu, y la de Silvia, hija del mismo Bertomeu, que censura la profesión y actitud 
del padre, pero disfruta del bienestar social que el dinero del progenitor le proporciona, sin cuestionar el origen delictivo del mismo:

A Collado le gusta leer libros sobre los temas que le enseñó su padre, revistas de armamento, de guerra [...]

Él ha heredado esa idea del hombre que le transmitió su padre [...] una forma de ver el mundo, tú a lo mejor no te das cuenta, le decía su padre, y eso es lo que heredas [...] el ojo de tu padre está anclado en esa idea de que el hombre ha matado para vivir y las formas que ha tomado la muerte, ese trabajo eterno del hombre, artesano de la muerte. [...]

Cinismo y amargura son los dos frutos que te da el árbol de la vida (Chirbes, 2007: 73, 76).

Silvia está convencida de que ese realismo que lo tira todo a ras de suelo arraiga en la vieja miseria de la comarca, en los restos nunca suficientemente lavados del franquismo. [...] De los cataclismos del mundo, de la sociedad, somos sólo espectadores. Los contemplamos con la misma impotencia con que los científicos de un observatorio meteorológico siguen el avance de un destructivo huracán (Chirbes, 2007: 270).

Más adelante, Silvia realiza una lectura determinista de la realidad española y justifica el malestar actual en los dos mil años precedentes, aunque remarca la visión que su madre Amparo tenía de la España del siglo $\mathrm{xx}$ :

Tenía razón su padre, ella, Silvia, formaba parte de la generación privilegiada. En los últimos dos mil años de historia de España todas las generaciones han crecido en guerra, peleándose unos contra otros contra la horda, la fratría o el clan de enfrente, este ha sido un país mugriento. Campesinos y artesanos famélicos, pintores famélicos y sucios, escritores famélicos y sucios, un país de porquería 
escasamente pasado por agua (su madre dixit). Casposas fotos de principios del siglo $X X$, una carga que se prolongó hasta hace muy pocos años. También las fotos de los sesenta destilaban cutrerio [...] y no digamos ya las fotos de los años cuarenta y cincuenta, esos hombres bajitos y cetrinos [...] La delicadeza de su madre: nunca soportó la sociedad española (Chirbes, 2007: 280-290).

\section{DEMOCRACIA DEGRADADA}

Los personajes de Crematorio, y en particular el de Rubén Bertomeu, son los que mejor reflejan la imposibilidad de regeneración de la sociedad española, puesto que el desafecto y la necesidad de sobrevivir, desde la Guerra Civil hasta la Transición, se prolongan durante la democracia, que no ha dado origen a una reacción ética contra el totalitarismo franquista, sino a una prolongación de un modelo de dominación que se ampara en premisas liberales ${ }^{23}$. En todo este tiempo, la familia ha seguido siendo una fuente de conflicto por la continuidad de la precariedad y de las rencillas ideológicas y personales; el bienestar y el interés propios han seguido primando por encima del bien colectivo; se han mantenido las prácticas corruptas y de dudosa legitimidad, los abusos de autoridad, la desigualdad, la indefensión de los más desfavorecidos; y han seguido proliferando los advenedizos que no persiguen tanto el poder como el dinero, que permite actuar con impunidad ${ }^{24}$ :

[Rubén Bertomeu] Si Matías hubiera nacido treinta años después, en vez de un autoritario estalinista $[\ldots]$

23. Sobre el paso del franquismo a la democracia, Chirbes (2015: 59) declaró: "El pacto [de la Transición] que se les propuso a los españoles, bajo el razonable argumento de cambiar pasado por futuro, fue un cambio de ideología por bienestar; es decir, un trueque de verdad por dinero. Y el país lo aceptó. De hecho, quienes proponían esa transacción eran jóvenes que exhibían sus credenciales antifranquistas, reales o contrahechas". "La Transición no fue un pacto sino la aplicación de una nueva estrategia de dominio de los menos sobre los más, y donde si hubo poca crueldad fue porque, por entonces, los menos eran fuertes y débiles los más" (Chirbes, 2002: 108). Moreno-Caballud (2012: 541-542) conecta esta visión instrumental e individualista de Chirbes con algunas propuestas de Sánchez Ferlosio. Calvo Carilla (2013) estudia el relato de la Transición en La larga marcha, La caída de Madrid, Los viejos amigos y Crematorio.

24. Chirbes (2010: 29) comentó sobre la sociedad democrática española surgida tras la Transición: "Los arribistas de ambos bandos habían tomado el poder de la nueva España y escribían la historia a su medida. Los recién llegados — muchos de los cuales se apresuraban a enriquecerse - no tenían la difusa sensación de culpa que marcaba a la vieja capa dominante, engordada a la sombra de la dictadura". 
seguramente habría sido - como su hijo- un escualo de la economía libre [...] La genética transmite caracteres que se adaptan a los papeles que reparte en cada época el teatro del mundo (Chirbes, 2007: 179).

[Ruben Bertomeu] La familia no ha llevado nunca a ninguno de sus miembros a destilar grandes sentimientos positivos, ternura, amor, ilusiones, nada de todo eso; todo lo más, corrección, buenos modales (Chirbes, 2007: 204).

A Collado le duele que los suyos no lo tengan: un padre que está en casa a primera hora de la noche, beso en la frente, cunita, camita [...] (Chirbes, 2007: 251).

[Mónica, segunda mujer de Rubén Bertomeu y unos treinta años más joven que él] ${ }^{25}$ Su madre y su hermana asustadas ante una vida como la que ella tiene ahora, con la seguridad que te otorga un marido setentón y cargado de dinero (Chirbes, 2007: 46).

[Rita pone en boca de su marido Juan las palabras siguientes] "Pues claro, cada uno a lo suyo, eso es lo bonito; que cada uno vaya a lo suyo, se meta en sus cosas y no en las de los demás, y todo el mundo viva. Lo otro, lo de que empiecen a controlarse los unos a los otros, es el principio de las dictaduras (Chirbes, 2003: 59).

Por el contrario, las pocas referencias de Chirbes previas a la Guerra Civil en sus novelas presentan un mundo mucho más gozoso, en el que las relaciones de familia eran cariñosas y felices, y la sociedad republicana mucho más paritaria pese a sus estrecheces ${ }^{26}$ :

25. A diferencia de otros personajes de Crematorio, Chirbes no especifica el apellido de Mónica, que procede de una familia humilde y quizá trabajó como prostituta, y cuyo verdadero nombre es Gregoria: "lo de Mónica es ficción" revela el personaje de Silvia (Chirbes, 2007: 303).

26. El propio Chirbes (2002: 105, 108-109) asumió estas ideas: "Vemos las fotografías de los primeros años de la República y sentimos especial emoción: los obreros y artesanos envueltos en banderas tricolores, los tranvías repletos de gente sonriente, y, enseguida, vemos las imágenes de los dramáticos instantes en los que el pueblo se apresura a parar el golpe fascista [...] 'ni siquiera los muertos estarán a salvo del 
[Apuntes del padre de Esteban] Echo tanto de menos las conversaciones con mi padre, con mi amigo Álvaro, a los dos se los quitaron de en medio, a Álvaro lo hicieron polvo en la cárcel, a mí también, pero, no sé si por suerte, yo tenía más salud, él salió amargado y enfermó y duró poco. Yo he sabido convivir con la amargura e impedirle que me arrebatara la salud. En fin, soy de otro planeta. Pero es lo que me he buscado. Lo que me han autorizado a buscarme [...]

Salamanca fue el destino de nuestro único viaje de estudios durante la República, gracias a una beca que nos otorgó a algunos alumnos una fundación no recuerdo si sueca $u$ holandesa (Chirbes, 2013: 351-352).

En la España republicana ya no había esclavos porque tampoco quedaban señores (Chirbes, 1996: 67).

\section{FINAL}

En conclusión, para Chirbes y para sus personajes la Guerra Civil es el origen de los problemas de la España actual, puesto que el conflicto dio paso a una lucha atroz por la supervivencia e impuso un gobierno dictatorial que no premió la bonhomía, el esfuerzo o el talento, sino la adhesión a ideales fascistas, con todo lo que ello supuso: sumisión, adulación, sinrazón, injusticia, corrupción, traición, frustración, ira, dolor ${ }^{27}$. Los individuos que sobrevivieron a la Guerra fueron incapaces de empatizar con sus iguales y de actuar de un modo tierno y solidario, porque la única forma de superar las limitaciones de aquel tiempo era "mancharse en tareas indignas". Estos factores impidieron la regeneración social y pervirtieron el

enemigo, si este vence'. Benjamin añadía: 'Y este enemigo no ha dejado de vencer' [...] esas palabras del filósofo alemán [...] nos advierten de que somos actores de un nuevo acto de esta obra interminable en la que, como aves de presa, luchamos por repartirnos las esperanzas de esas caras sonrientes de los primeros días de la República y también el sufrimiento de los rostros que se vuelve más atroz a medida que avanza la guerra, y los cascotes de los edificios caídos, y los muertos".

27. Chirbes evocó: "En el colegio de huérfanos [de Ávila], uno valía por su propio esfuerzo y no - como ocurría en Salamanca - por el apellido, el negocio de los padres o la ropa que llevaba. Esa idea de que cada persona se sostiene a sí misma aún me acompaña" (López de Abiada, 2011: 14). 
comportamiento de los descendientes de quienes lucharon en el conflicto, que no fueron capaces de construir una sociedad más igualitaria y ética, ni siquiera después de la dictadura. La consecuencia de todo ello es una España injusta e individualista, que abunda en el abuso de poder y los intereses personales, tal y como se sigue reflejando en las familias, donde se suceden las disputas por rentas y propiedades, y en miembros de los diferentes gobiernos democráticos, condenados por nepotismo, corrupción o fraude ${ }^{28}$. Chirbes (2002: 99 y 102) hace suyas así dos de las conclusiones que le suscitó la lectura de Si te dicen que caí, de Juan Marsé: “[...] de las ruinas de una generación derrotada surge otra corrompida y enferma [...] Tras la devastación, no hay formas de inocencia: todo es malsano residuo [...] nosotros mismos, culpable residuo".

Esta lectura histórica de la sociedad española hecha por Chirbes, que tan buena recepción ha tenido en Alemania, se asemeja, por ejemplo, a la efectuada por el director de cine Michael Haneke sobre la Segunda Guerra Mundial en Das weiße Band - Eine deutsche Kindergeschichte, donde el clima represivo y violento en el que crecen los dos niños alemanes protagonistas del filme explicaría la crueldad del conflicto y el holocausto judío ${ }^{29}$.

\section{REFERENCIAS BIBLIOGRÁFICAS}

\section{AMAR SÁNCHEZ,A. M.(2010). Instrucciones para la derrota. Narrativas éticas y políticas de perdedores. Rubí, Barcelona: Antrhopos. ANIORTE, J. (2011). "Rafael Chirbes, traducción y reconocimiento en}

28. Chirbes reconoció que su generación, a pesar de ser la primera en la historia de España que no vivió una guerra, fracasó tanto como la de sus padres por haber amparado un capitalismo salvaje: "La [generación] de mis padres fue a la guerra y la mía [es] la del liberalismo por todos los medios" (Corominas i Julián, 2013).

29. A este respecto Chirbes (2002: 29-30) recordó la huella que le produjo la lectura de la novela Una fuente inagotable, de Martin Walser, sobre "la infancia alemana durante los años del nazismo". Los personajes de Chirbes también se refieren a este conflicto: [Rubén Bertomeu] "La locura de Alemania de entreguerras: tuvo que ir Hitler a ponerles un poco de orden, a rehacer las élites. Claro que se pasó en la purga, porque, al final, resultó que no era un político, era un depredador, un carnicero, no un estadista [...] Su abuelo [el del escritor alcoholizado Federico Brouard], un pobre alfarero [...] que nadie sabía cómo había llegado a la comarca [Misent], huyendo del hambre, de alguna guerra, y que le había regalado ese apellido extranjero que, de pequeño, parecía que le disimulaba la pobreza, el alfarero Brouard" (Chirbes, 2007: 59, 132). Todos estos hechos se podrían relacionar a su vez con los estudios sobre el trauma o la condición postraumática, síndrome que sufren los personajes de Chirbes que han sobrevivido a la Guerra y a la dictadura, pero también podría ser aplicado a los personajes que asisten a una catástrofe, a la muerte de un ser querido... (Caruth, 1996). 
Alemania: los paisajes del alma". En Las letras valencianas en la literatura universal. Problemas de recepción y traducción: el paisaje y el tiempo, J. A. Albadalejo Martínez y M. A. Vega Cernuda (eds.), 149-156. Sevilla: Bienza.

ARMADA, A. (2013). "Rafael Chirbes: 'No hay riqueza inocente"”. $A B C$, http://www.abc.es/cultura/libros/20130526/abci-entrevista-rafaelchirbes-201305241354.html [25/11/2016].

BAJTín, M. (1986). Problemas de la poética de Dotoievski. T. Bubnova (trad.). México: Fondo de Cultura Económica.

BERCIANO LÓPEZ, L. (2015). "En la orilla" de Rafael Chirbes. Lugo: Universidad de Santiago de Compostela. Trabajo de Fin de Grado, disponible en línea: https://minerva.usc.es/xmlui/ handle/10347/14960 [18/09/2017]

BOBES NAVES, C. (1993). La novela. Madrid: Síntesis.

CALVO CARILLA, J. L. (2013). "Lecturas críticas sobre la Transición: el caso de Rafael Chirbes". En El relato de la Transición / La Transición como relato, J. L. Calvo Carilla, C. Peña Ardid, M. Á. Naval, J. C. Ara Torralba y A. Ansón, 119-146. Zaragoza: Prensas de la Universidad de Zaragoza.

CARUTH, C. (1996). Unclaimed Experience: Trauma, Narrative, and History. Baltimore: The John Hopkins University Press.

CHIRBES, R. (1996). La larga marcha. Barcelona: Anagrama. (2000a). La buena letra. Barcelona: Debate. (2000b). La caída de Madrid. Barcelona: Anagrama. (2002). El novelista perplejo. Barcelona: Anagrama. (2003). Los viejos amigos. Barcelona: Anagrama. (2007). Crematorio. Barcelona: Anagrama. (2010). Por cuenta propia. Leer y escribir. Barcelona: Anagrama. (2011). Los disparos del cazador, Ignacio Muñoz (ed.). Madrid: Castalia.

(2013). En la orilla. Barcelona: Anagrama, $6^{\mathrm{a}}$ ed. (2015). "Pecados originales". Página abierta 240, 58-59, http:// www.pensamientocritico.org/rafchi1015.htm [26/11/2016].

COEN, S. (2012). Historia y ficción: El desencanto en la sociedad derrotada en "Crematorio" (2007) de Rafael Chirbes. Gent: Universiteit Gent. Trabajo Fin de Máster, disponible en línea: https://lib.ugent.be/en/ catalog/rug01:001891661 [18/09/2017] 
COROMINAS I JULIÁN, J. (2013). "Diálogo con Rafael Chirbes". Revista de Letras, 27 de marzo: http://revistadeletras.net/dialogocon-rafael-chirbes-por-jordi-corominas-i-julian/ [10/11/2016].

DOMÍNGUEZ GARRIDO, A. (1996). El texto narrativo. Madrid: Síntesis. ECHEVERRÍA, I. (2005). Trayecto. Un recorrido por la reciente narrativa española. Barcelona: Debate.

GARCÍA DE LEÓN, E. (2006). "El miedo, legado generacional en los personajes de Chirbes". En Ensayos sobre Rafael Chirbes, M. T. Ibáñez Ehrlich (ed.), 31-58. Madrid / Frankfurt am Main: Iberoamericana / Vervuert.

GARCÍA LARISCH, C. (2015). ;Manda narices! El paisaje olfativo de En la orilla de Rafael Chirbes. Lund: Lunds Universitet. Trabajo Fin de Máster, disponible en línea: https://lup.lub.lu.se/student-papers/ search/publication/4255215 [18/09/2017]

GARCÍA PASCUAL, R. (2011). "Lectura psicocrítica de La larga marcha (1996), de Rafael Chirbes". En La constancia de un testigo. Ensayos sobre Rafael Chirbes, A. López Bernasocchi y J. M. López de Abiada (eds.), 109-125. Madrid: Verbum.

HIGUERO, F. J. (2003-2004). "Horizonte nihilista en Los viejos amigos, de Rafael Chirbes". Castilla 28-29, 131-144.

JACOBS. H. C. (1999). "Las novelas de Rafael Chirbes". Iberoamericana 23, 175-181.

JULIÁ, S. (2003). "Política y sociedad durante el Régimen de Franco". En Sociedad y política almeriense durante el régimen de Franco. Actas de las Jornadas celebradas en la UNED durante los días 8 al 12 de abril de 2002, M. Gutiérrez Navas y J. Rivera Menéndez (coords.), 11-31. Almería: Instituto de Estudios Almerienses.

KUNDERA, M. (1987). El arte de la novela. F. de Valenzuela y M. V. Villaverde (trads.). Barcelona: Tusquets.

LLAMAS MARTÍNEZ, J. (2017). "Una aproximación al ritmo lingüístico, el tono y la puntuación en las novelas de Rafael Chirbes". Tonos Digital. 32, 1-28.

LODGE, D. (2002). El arte de la ficción, L. Freixas (trad.). Barcelona: Península.

LÓPEZ, I. y RODRÍGUEZ, E. (2010). “El modelo español (Resumen)”. En Fin de ciclo: financiarización, territorio y sociedad de propietarios en la onda larga del capitalismo hispano (1959-2010). Madrid: 
Traficantes de Sueños.

LÓPEZ BERNASOCCHI, A. y LÓPEZ DE ABIADA, J. M. (2011a). "Hacia Crematorio, de Rafael Chirbes. Guía de lectura". En La constancia de un testigo. Ensayos sobre Rafael Chirbes, A. López Bernasocchi y J. M. López de Abiada (eds.), 279-369. Madrid: Verbum.

(2011b). "Hacia La larga marcha, de Rafael Chirbes. Guía de lectura". En La constancia de un testigo. Ensayos sobre Rafael Chirbes, A. López Bernasocchi y J. M. López de Abiada (eds.), 179218. Madrid: Verbum.

(2011c). "Hacia Los viejos amigos". En La constancia de un testigo. Ensayos sobre Rafael Chirbes, A. López Bernasocchi y J. M. López de Abiada (eds.), 219-278. Madrid: Verbum.

LÓPEZ DE ABIADA, J. M. (2011). "Entrevista a Rafael Chirbes". En La constancia de un testigo. Ensayos sobre Rafael Chirbes, A. López Bernasocchi y J. M. López de Abiada (eds.), 12-20. Madrid: Verbum. LUENGO, A. (2004). La encrucijada de la memoria. La memoria colectiva de la Guerra Civil española en la novela contemporánea. Berlín: Tranvía / Walter Frey.

LÓPEZ MERINO, J. M. (2005). "Calas en la La caída de Madrid”. Tonos Digital 9, 292-307.

MAESTRO, J. (1994-1995). "Semiología del personaje literario: La melodramática vida de Carlota-Leopolda". Archivium 44-45, 447495.

MORALES OLIVAS, L. (2006). "El elemento lírico en la narrativa de Rafael Chirbes". En Ensayos sobre Rafael Chirbes, M. Teresa Ibáñez Ehrlich (ed.), 159-174. Madrid / Frankfurt am Main: Iberoamericana / Vervuert.

MORENO-CABALLUD, L. (2012). "La imaginación sostenible: culturas y crisis económica en la España actual”. Hispanic Review 80, 535555.

MUÑOZ MOLINA, A. (1996). "En folio y medio". El País, http:// elpais.com/diario/1996/10/09/cultura/844812012_850215.html [26/11/2016].

NICHOLS, W. J. (2008), "Sifting through the Ashes. An interview with Rafael Chirbes". Arizona Journal of Hispanic Cultural Studies 12, 219-235. 
ORSINI-SAILLET, C. (2010). "Regards sur la Transition dans le roman espagnol actuel: 'La caída de Madrid' de Rafael Chirbes et 'Romanticismo' de Manuel Longares'. Langues néo-latines 354, 6588.

POZUELO YVANCOS, J. M. (2010). 100 narradores españoles de hoy. Palencia: Menoscuarto.

ROBERTO ÁNGEL, G. (2007). "La degradación del hombre como influencia del espacio en la novela Mimoun, de Rafael Chirbes". Espéculo 34, https://pendientedemigracion.ucm.es/info/especulo/ numero34/naturesp.html [12/05/2016].

SÁNCHEZ ALONSO, F. (1998). "Teoría del personaje narrativo. (Aplicación a El amor en los tiempos del cólera)". Didáctica. Lengua y literatura 10, 79-105.

SANTAMARÍA COLMENERO, S. (2011). “'Las sombras” de Rafael Chirbes. La memoria de vencidos y vencedores en La buena letra y Los disparos del cazador". Revista de Estudios Vascos 8, 200-217. (2013). Las palabras como acontecimiento: Segunda República, Guerra Civil y Posguerra en la novela actual (1990-2010). Valencia: Universidad de Valencia. Tesis doctoral. (2015). "Traición y memoria. 'Los disparos del cazador"”. Turia 112, 244-250.

SCHMITZ, S. (2006). "La caída de Madrid, una novela histórica de Rafael Chirbes o el arte nuevo de cometer un deicidio real(ista) en el siglo XXI". En Ensayos sobre Rafael Chirbes, M. Teresa Ibáñez Ehrlich (ed.), 201-233. Madrid / Frankfurt am Main: Iberoamericana / Vervuert.

VAL, F. del (2015). "Biocronología de Rafael Chirbes". Turia 112, 280305.

WOOD, J. (2009). Los mecanismos de la ficción. A. Herrera (trad.). Madrid: Gredos.

ZOLA, E. (2002). El Naturalismo. J. Fuster (trad.), Barcelona: Península.

Recibido el 1 de marzo de 2017.

Aceptado el 17 mayo de 2017. 